\title{
History, Epistemology, and Interdisciplinarity of Comparative Literature: A Study
}

Neethu Das. K

PhD Research Scholar

Dept. of English and Comparative Literature

Central University of Kerala

Kerala, India

neethudas1992@gmail.com

Abstract

The paper discusses the historical significance of the academic discipline Comparative Literature, focusing on key theorists and their arguments on the methodological nuances of the discipline. The paper distinctly presents the disciplinary associations of Comparative Literature and tries to frame it from a reader's perspective. The status of Comparative Literature in academia highlighting the historical timeline is discussed along with presenting the crisis the discipline has faced/faces in its methodological approach.

Keywords: Interdisciplinarity, Comparative Literature, Literary Revival, Methodology, Translation

Comparative Literature revolts against the Arnoldian concept of 'the best that is known and thought in the world'. The world had some set 'superlatives' and 'canons' which ruled and led the world and suppressed other ideas. It was against this ideal norm that Comparative Literature resisted and got placed. Susan Bassnett defines Comparative 
Literature as one which "involves the study of texts across cultures that it is interdisciplinary and that it is concerned with patterns of connection in literatures across both time and space" (1). Comparative Literature arises from an urge or instinct to move out of a subject or from a quest done within the similarities in cultural contexts between texts or authors. This argument can be contextualized to what Matthew Arnold in his Inaugural Lecture at Oxford in 1857 has said "Everywhere there is connection, everywhere there is illustration. No single event, no single literature is adequately comprehended except in relation to other events, to other literatures"(qtd. in Ray 106).Comparative Literature is more a result of the quest for knowledge, which moves a reader of Shakespeare to Dante or Boccacio. The reader who attempts Chinua Achebe is connected tothe literary world of Marquez and Marquez to Khushwanth Singh, breaking the barriers of languages. Here, readers connect their aesthetic literary sensibility to the history of colonization and trauma of the colonized.

This reader response is generated as a reaction to the imperial arrogance existing in the society regarding Literature. The arguments in canonical critical texts like Ian Watt's "Rise of the Novel" are grounded within English Novel. Correspondingly, Salman Rushdie's edited work Anthology of Indian Literature is just a collection of Indian English works and does not include any works from regional Literature. These universal movements which uphold the colonial canons are subverted in Comparative Literature, which crosses boundaries to the regional languages.

The term 'Comparative Literature' appeared when independence movements were organized in European nations and new nation-states emerged. This resultant 'spirit of nationality' has helped comparative literature along with the resistance movements. In Byron's Prophecy of Dante, Byron talks about the notion of Italians who disapprove of a foreigner's contribution to a nation in the grounds of their nationality. Byron observes that a nation engaged in struggles for independence jealously guarded its literary heritage against all 
foreigners. The revival of folk tales and fairy tales, archaic manuscripts, and oral popular culture was specifically featured in these upheld cultural identity movements. The emergence of Irish literary revival against the English centralism was a project of nationalistic revival of Ireland. The creation and perpetuation of cultural homogeneity against the cultural imperialism of the colonizer gained momentum in many European nations subsequently.

The American Revolution of 1776 shook the world significantly and set the English language to a new path variant from that of Eurocentrism. American Literature's development evoked many questions. Though American English Literature modelled English writers, it was manifested and identified as a separate province. Latin American writers were also marked with their unique cultural identity in their writings in the English language. This based the concept of World Englishes, recognizing localized or indigenized varieties of English, which reclaimed space in individual literatures also.

The discipline of Comparative Literature slowly emerged, breaking all its barriers evolving with two mainstream ideologies, namely the French perspective and the German perspective. Later, with the emergence of the 'new world', a third vision gained importance, the American school of Comparative Literature. The concept of Comparative Literature, which involved a consideration of more than one Literature, was discussed in Europe in the early $19^{\text {th }}$ century. The beginning of the notion of comparison in Literature arose from the typical scientific practice of reaching to a hypothesis by comparing or contrasting. The world was getting empowered with two perspectives on Comparative Literature, the French and German perspectives. The French perspective oriented more to the study of cultural transfer. They assumed that Comparative Literature was all about knowing ourselves, a concern with the study of the production of humanity. Meanwhile, German perspective was also promoted where Comparative Literature was equated to the knowledge of literary history. 
By the late $19^{\text {th }}$ century, the discipline acquired academic status as well. The French school of Comparative Literature dominated the field, focusing on the study of influences. Susan Bassnett notes that the first chair of Comparative Literature was at Lyon, France in the year 1897. In American academia, Charles Shack well taught 'General or comparative literature' from 1871 at Cornell University. Similarly, Charles Mills Gayley taught Comparative Literary Criticism at the University of Michigan from 1887.The first chair was set up in the United States of America in 1890 at Harvard University. H.M Posnett published a study on the subject 'Comparative Literature' in 1886. Posnett's evolutionary model and Gailey's melting point idea differed from the prior European models. The process of depoliticization of the discipline is a characteristic feature of the American school.

In 1903, Benedetto Croce, literary critic and historian, argued that Comparative Literature was a non subject, and he dismissed the argument of seeing it as a separate discipline. Parallelly, Translation Studies has emerged as an independent discipline with professional associations, journal publications and articles, publishers' catalogues, and doctoral theses. The relationship between Comparative Literature and Translation studies is dense and elusive. Translation was always intellectually sidelined as the poor relation, being considered as an activity involving little talent and creativity. Hillarie Belloc, writer and historian in 1931, said, "The art of translation is a subsidiary art and derivative. On this account, it has never been granted the dignity of the original work and has suffered too much in the general judgement of letters" (qtd. in Antes 111).

Though the art of translation is long established, the study of the field as an independent academic discipline was manifested only in the second half of the twentieth century. "Comparative Literature was only a parallel approach where Literature is studied and compared transnationally and transculturally, necessitating the reading of some literature in translation"(Munday 15). Accordingly,a good comparative critic should only read original 
texts in the original language then. Susan Basnett opines that "Comparative Literature has had its day.Cross Cultural work in women's studies, in post colonial theory, in cultural studies has changed the face of literary studies generally.We should look upon translation studies as the principal discipline from now on, with Comparative Literature as a valued but subsidiary subject area"(161). "Crisis of Comparative Literature" (1959), written by Rene Wellek, widely regarded as American School of Comparative Literature's manifesto, emphasizes the importance of literary theory and champions 'cosmopolitan humanism over cultural nationalism'. According to Wellek, Comparative Literature is confined to the interrelation between two literatures, while general literature is a collection of movements and fashions that sweep across several literatures (167). Wellek attacked the methodology of the academic discipline Comparative Literature and the prejudiced nationalism which is highlighted. He accused Van Tieghem's definitions of Comparative Literature for restricting the scope of Comparative Literature and putting forth an approach that led nowhere (164-7).

Susan Basnett comments on Comparative Literature that subsequent generations of younger scholars will turn away from the subject as it appears to be irrelevant and antiquated. She points out that the crisis of the discipline is because of its defiance to consider the political implications of intercultural transfer (159). While most theorists suggest and manifest the superiority of translation studies as an advanced and grounded discipline than Comparative Literature, Gayatri Chakravorty Spivak, literary theorist, recommends the need for an association of Comparative Literature with Area Studies (19). Spivak sees Comparative Literature as a discipline that can train the imagination to listen to the other. She wants a new Comparative Literature that can be "world embracing and whose hallmark remains a care for language and idiom" (5). The political understanding of a literary work with fundamental knowledge in its geographical and historical implications can affirmatively influence when the work is subjected to a comparative criticism. Comparativism has to 
approach diversified ethical systems diachronically, which is more successful through language based literary investigation than through cultural evidences. The ability of literary works to fix and cajole prejudices and otherings can be overturned with solid political understanding. Spivak cites an example from J.M Coetzee's novel Waiting for the Barbarians (1980), showing how the colonized are portrayed through the viewpoint of a young imperialist officer's character (20).

The inability to provide an exact definition and methodology of Comparative Literature shows its openness to all disciplinary approaches and literary theories, regardless of cultural origin. But it also lies as the most significant drawback of the discipline. Anything that discusses art and literature, traces the influence of film within textual studies or takes post-colonialism as their central theme encapsulates the comparative spirit. This indicates that there is no need to isolate one art form from another or limit literary studies to one national culture. As Spivak clearly pointed out, collaboration between the disciplines will help to leave the notion of the dominant self. Though 'literary' is not a blueprint for social action, it can be if literature is also taken as an object of investigation. Spivak feels that there is a utopian notion in presenting the two disciplines together. The fear of disciplinarity hinders a mutual connection as the growth of literariness is feared by Social Sciences. The discipline of Social Sciences fears their trivialization into "their rational expectation straitjackets" (Spivak 19). 
Bibliography

Antes, Peter., Armin.W.Geertz, and Randi.R.Warne.New Approaches to the Study of Religion. Germany: Walter de Gruyter, 2004.Print.

Bassnett, Susan. Comparative Literature: A Critical Introduction. UK: Blackwell Publishers, 1993.Print.

Bhaduri, Saugata and Amar Basu. Perspectives on Comparative Literature and Culture in the Age of Globalisation. India: Anthem Press, 2010. Print.

Damrosch, David., Natalie Melas, and Mbongiseni Buthelezi.Princeton Sourcebook of Comparative Literature. New Jersey: Princeton UP, 2003. Print.

Munday, Jeremy. Introducing Translating Studies: Theories and Applications. London: Routledge, 2016. Print.

Raj, Rizio Yohannan. Quest of a Discipline. New Delhi: Cambridge UP, 2012. Print.

Ray, Mohit.K. Studies in Literary Criticism.New Delhi: Atlantic, 2002.Web.

Spivak, Gayatri Chakravorty. “Crossing Borders.” Death of a Discipline.London: Columbia UP, 2003. 1-24.

Wellek, Rene. "The Crisis of Comparative Literature" Princeton Sourcebook of Comparative Literature. Eds. David Damrosch et al. New Jersey: Princeton UP, 2003. Print. 161172. 